ARTICLE

https://doi.org/10.1057/s41599-019-0306-x

\title{
Thinking in rural gap: mobility and social inequalities
}

\author{
Luis Camarero ${ }^{1} \&$ Jesús Oliva ${ }^{2}$
}

\begin{abstract}
The impact of the global financial crisis and the economic recession on Southern European countries has threatened the rural welfare of many regions. The loss by emigration of the young population, austerity policies, and the territorial concentration of essential services have led many of rural areas into a spiral of decline. The growth of regional disparities, even among rural areas, is confirmed by the European official reports. Depopulation and rural decline are highly associated with remoteness. Accessibility is one key issue to mitigating this erosion of socio-territorial cohesion; another is mobility, which is the usual way to confront the scarce opportunities and limited services in deeply rural territories. This paper pays attention to socio-territorial inequalities and considers as working hypothesis that social rights are differentiated by the habitat structure; as a result, territory determines different degrees of citizenship. Traditional perspectives focused on the access to productive resources and material opportunities as the source of disadvantages, but we suggest that a more comprehensive approach is needed to address the rural gap: the difference between living conditions and living expectations in rural areas in contrast with urban ones. We address two main processes involved on it. On the one hand, there are strong interconnections between physical and social mobility, such as commuting to distant labor markets and educative centers, which could increase the social mobility of rural youth. On the other hand, the maps of the provision of services, infrastructures networks and investments not only reshape the territories but also their sociological morphologies. Accessibility and mobility are strongly linked with rural well-being and social sustainability. We explore and illustrate these questions with examples from the Spanish case. The text is structured into four issues regarding the rural gap: the territorial imbalance and social cohesion, the demographic imbalance and rural welfare as the product of the inter-generational equilibrium, the rural disparities in accessibility and the challenges of mobility transition. Finally, we conclude with a discussion of the rural policies and governance required for achieving social and territorial balance.
\end{abstract}

\footnotetext{
${ }^{1}$ National Distance Education University, Madrid, Spain. ${ }^{2}$ Public University of Navarre, Pamplona, Spain. Correspondence and requests for materials should be addressed to L.C. (email: Icamarero@poli.uned.es)
} 


\section{Introduction}

n twenty-first century Europe, the rural world continues to be seen as a problem. However, the diagnosis has tended to consider its causes today, not so much in the underdevelopment, but in the lack of attractiveness to avoid outmigration by the youth and women (Shucksmith, 2010; Vidickiene, 2017), to attract new residents (Elshof et al., 2017), to compete in attracting business and jobs (Meijers and van der Wouw, 2019), to retain professionals (Fleming and Sinnot, 2018) and for the maintenance of services such as health professionals. In 1998 the European Commission expressed their concern about the situation in rural areas with the report "The future of rural society". Almost three decades later, the new 2016 Cork 2.0 Declaration, pointed again to the importance of the rural question. The first report brought about the implementation of rural development policies, but the last Cork Declaration demonstrates the insufficient economic development, which despite improving and adapting rural economies, has been unable to reduce population loss. Now the challenge is to improve the conditions for the quality of rural life.

In terms of vital opportunities, rural habitat continues to maintain notable differences over urban areas. In this sense, we can speak of the rural gap. On the one hand, in the sphere of economic development because of the persistence of the rural penalty. As noted by Hite (1997) or Malecki (2003), distance and low population density affect socioeconomic differences. On the other hand, these features of rural habitats-small villages, dispersed population, and low density-have not allowed an equal integration in the conditions of the welfare state (Shucksmith and Chapman, 1998). That is, in rural areas, there are not only fewer employment or consumption opportunities but also regarding welfare conditions, for example, greater difficulties in the work and family reconciliation and accessibility to public services and resources. The 2016 OECD report insists on pointing out the gap produced by distance to urban centers in terms of economic dynamism and its extension to living standards and well-being.

The rural gap is primarily a problem of social inequality and, politically, it has turned from being considered as a question of economic development, to being seen as an issue of social cohesion. For example, depopulation has been introduced into the agenda and into the traditional actions of the first and second pillar of the Common Agricultural Policy. Modulations have been established in the application of European Structural and Investment Funds (ESI funds) for sparsely populated regions with less than 50 inhabitants per $\mathrm{km}^{2}$, and for very sparsely populated with a density of less than 8 inhabitants per $\mathrm{km}^{2}$-(Margaras, 2016).

Social inequalities are not only of an economic nature; they also include the conditions of social reproduction and cultural distinction (Savage et al., 2005), as well as those of appropriation and social production of space (Lefebvre, 1967; Soja, 2010). This paper is an approach to the rural gap from the understanding that social inequalities are not static but determined in every moment and place and, as Green and Hulme (2005) pointed out, are continuously produced. For over a decade we have been addressing the issue of rural sustainability in Spain (Camarero, 2009) and have further develop this analysis through different papers (Camarero et al., 2016). From these findings we elaborate here the question about the "rural gap", which links up with the open public debate in the country on the policies to deal with rural depopulation. On the one hand, the crisis has accentuated the situation, revealing the scope and complexity of the problem (Bayona-i-Carrasco and Gil-Alonso, 2013; Collantes et al., 2014; Sampedro and Camarero, 2018; Oliva and Camarero, 2019). On the other hand, the importance acquired by these issues has led the Spanish government to the creation of a special
Commissioner and a National Strategy against the Demographic Challenge (Ministerio de Política Territorial y Funciónn Pública, 2019).

The text explores this idea-the rural gap-as a source of citizen inequality by focusing on four concatenated issues: habitat structure, demographic imbalances, accessibility, and mobility transition. Today urban-rural differences are expressed in demographic terms: rural and urban populations are groups with very different living conditions that involve also very different demands for economic participation, consumption, and wellbeing. The principle of a uniform configuration of the supply of services in the face of the real diversity of territorial situations predetermines the accessibility to public goods and resources aimed at the reduction of inequalities. The decrease in accessibility involves a greater demand for mobility and makes mobility a source of new inequalities that feedback the vicious circle of the rural gap.

\section{Social cohesion and territorial imbalance}

The process of progressive of-agrarization and the creation of multifunctional rurality have been generating a situation of strong territorial imbalance in the demographic distribution. It is not just a mere transfer of the rural population to urban and industrial areas, but a rural restructuring (Marsden, Lowe and Whatmore, 1990) that has meant a process of true regional differentiation. For example, in the case of the Iberian Peninsula, during the last decades of the twentieth century, a territorial concentration of the population has been observed in large urban areas, as well as in the coastal regions; this contrasts with a progressive emptying of the interiors of Spain and Portugal. Although these countries are where there has been a greater intensity, it is a generalized process in other Mediterranean countries such as Greece, southern Italy, Bulgaria, Romania, Northern and Eastern Europe, and inland Germany (vid. ESPON, 2017).

It is evident that the depopulation of inland regions has repercussions for the vital capacity and the economic development of the territories. Nevertheless, within the context of the welfare state, the loss of political weight of the territories and their inhabitants has become even more remarkable. The territorial imbalance brings important inequalities in political opportunities, and lower demographic weight implies less political strength. In practice, it means a weak construction of citizenship in the small towns and regions because the territorial balance and the regular maintenance of the population in the territory is a condition of social cohesion. Different studies coincide in pointing out that the European zones in terms of depopulation show, for example, a higher school dropout rate and a higher proportion of people at risk of poverty (Delivorias and Sabbati, 2015). These areas contrast with regions of strong population attraction and economic activity.

In this sense, the rural gap can be interpreted in terms of social cohesion. On the one hand, the demographic shortfalls prevent rural areas from achieving critical volumes of social capital as stated in the Cork 2.0 declaration. In the current context of progress toward a knowledge-based economy, this social capital is especially crucial and the lesser disposition of it in rural areas ends up concentrating innovation processes in urban areas. As a consequence, the marginalization of rural areas increases $(\mathrm{Li}$, Westlund and Liu, 2019). On the other hand, the distribution of welfare policies based on aggregate demand criteria, in the face of territorial equilibrium criteria, implies unequal access by the rural population to public services (Shucksmith and Brown, 2016, Bock, 2019). 
The territorial characteristics-density and dispersionincrease the inequality of the rural inhabitants. The rural gap conditions the notion of citizenship insofar as it is recognized, due to the place of residence, access to different conditions of collective well-being.

There is a principle of basic equality in the commitment of the population and territory. The issue is that political rights acquired as citizens are universal but in practice are territorially modulated, because these rights become both exercised and enjoyed upon registration in a place. Not all territories and places have the same capabilities or offer the same resources for equal problems. Equality of rights requires territorial equality. Nonetheless, it is also relevant to address the biunivocal nature that is established between population and territory. The presence and distribution of a population throughout the territory allow it to control the resources that it houses and the environment. The victims of depopulation are not only rural inhabitants but the whole of society.

Different reports from the EU (ESPON, 2017) point out the importance of addressing territorial inequalities. The analysis shows a demographic "long winter" and the futility of thinking about regional rebalances in the medium term. The idea of coexisting in a Europe with strong territorial and demographic imbalances is the most probable scenario.

\section{Demographic imbalance: rural welfare and generational composition}

Within the inequalities generated by depopulation combined with territorial disadvantages, demographic imbalances are central. It is not simply the loss of population, particularly of young people, but that the relationship among the generations become profoundly altered. Depopulated areas are heavily aged but also masculinized at a young age. This phenomenon is evident in Spain and Portugal; however, it is deeper and more generalized in the eastern regions of Germany (Weist and Leibert, 2013).

The rural areas are in a situation of clear demographic imbalance that is the result of a very selective migratory balance. Rural masculinization is only a sample of the gender differences in opportunities produced by some factors that characterize the rural areas, like the restricted labor markets for women and particularly for qualified jobs and the reduced opportunity of access to care resources for children and elder people (Camarero et al., 2016). Aging and masculinization define rural family structures.

Within the configuration of what has been called "society of ageing" the cases of very high proportions of elderly people living in rural areas in southern and Mediterranean countries are especially notable (Goll, 2010). In these regions, the weighting of those over 65 exceeds the figure of $20 \%$ and it is near to the quarter of the total. The list of rural ageing is usually led by Spain with $26.8 \%$ of the population over 65 years and Portugal $24.7 \%$, followed by the Mediterranean countries of Greece $24.2 \%$, Italy 23.3\%, and France 22.8\% (Predominantly rural areas. 2017 data. Eurostat serie: urt_pjanaggr3). In the Spanish case, its effects can be glimpsed, for example, concerning caring needs. As the Eurostat data showed in 2014 (see Table 1), residents in rural areas reported greater dependency and, at the same time, increased needs due to the effect of chronic pathologies. The gap between rural-92\% need personal asisstance-and urban, less than $80 \%$-is prominent.

Beyond its strictly biological aspects, ageing must be understood as the specific product of a certain demographic sequence, in which there is a significant increase in life expectancy at all ages with a significant decrease in fertility. This demographic regime, known as "the second demographic transition" (van de Kaa, 1987;
Table 1 Need for help with personal care activities in the age group of 65 years or over by degree of urbanization (Spain)

\begin{tabular}{lllc} 
& Cities & Towns and suburbs & Rural areas \\
\hline No need for assistance & 20.6 & 17.3 & 8.8 \\
Get enough assistance & 34.7 & 37.0 & 36.9 \\
Lack of assistance & 44.7 & 45.7 & 54.3 \\
\hline
\end{tabular}

Source of data: Eurostat serie: urt_pjanaggr3, European Health Interview Survey, 2014

Lesthaeghe, 2007), has the effect that older generations take much longer to disappear and, therefore, their ageing and longevity process lengthens. This demographic process requires a new life stages map.

Low fertility is a second aspect of the "second demographic transition" that conditions the size of the new generations and directly affects the numerical imbalance among the generations. This imbalance entails the reorganization of relations among the generations through systems of interaction, among which the family stands out. In this way, the changes related to the care of the elderly deeply affect the way in which families organize themselves. It is not only fertility has been reduced, but also the age for commencing motherhood has been delayed in a way that the distance between generations is greater. This increase in the distance between generations can be understood from the perspective of the chains of care as an adaptive process. The children will not be so old when the parents reach the fourth age and in turn; those parents who become grandparents will also help with the upbringing of their grandchildren.

To a large extent and especially in rural areas, the upkeep of the ageing population process has been transferred mainly to families and particularly to women and groups such as the denominated "support generation". As a general rule, the weakness of southern welfare systems is that they favor more extensive family models. The Mediterranean family model has been highlighted by the classic work of Saraceno (1994) who considers that the importance of familism as a characteristic of Mediterranean societies that even affects the lack of development of certain social protection and social policies.

This causes the vicious circle of depopulation. Less population leads to the reduction of services and, therefore, family overload. Both situations generate even greater depopulation. The rural question is then a matter of social reproduction and depopulation has acquired the status of public debate and may be considered as kind of state issue.

\section{Accessibility: crisis, rural disparities, and services desertification}

Also parallel to the population desertification of certain territories may be the perceived desertification of services (such as the "medical desertification", (Legido-Quigley, et al., 2013) lack of bank services, low-quality internet). As illustrated by the case of Spain, investments in the railway network focused on high-speed connections between some main cities, while the budget to maintain the rest of the network has been progressively constrained; Spain boasts one of the most extensive in the world in relation to the ratio per inhabitant. In this country, the demands of regions and localities without investment in infrastructures, apart from train networks and with minimized services, gave rise to important local mobilizations that have sought to put the territorial problem onto the state agenda.

The impact of the crisis and the cuts derived from the austerity policies upon European rural areas have been significative (OECD, 2016; Congress of Local and Regional Authorities, 2017). 
Table 2 Rural accessibility gap in Spain

\begin{tabular}{|c|c|c|c|c|c|c|c|}
\hline & \multicolumn{3}{|c|}{$\begin{array}{l}\% \text { of household with some and great } \\
\text { deal difficulty of access }\end{array}$} & \multirow[b]{2}{*}{ Accessibility Déficit } & \multicolumn{3}{|c|}{$\%$ households using the service } \\
\hline & Rural & Spain & Metro-politan & & Rural & Spain & Metro-politan \\
\hline Banking services & 22.7 & 13.7 & 6.7 & 16 & 97.6 & 97.8 & 97.5 \\
\hline Postal services & 19.7 & 16.3 & 11.3 & 8.4 & 62.3 & 62.8 & 68.9 \\
\hline Public transport & 21.7 & 10.0 & 4.3 & 17.4 & 36.3 & 58.9 & 88.4 \\
\hline
\end{tabular}

This is particularly the case in the southern countries subject to expenditure control, where austerity policies have reduced the public and private rural services networks-postal offices, banks, public transport, social services, etc.- -divestments in projects and infrastructures have led to a growth of disparities even among the rural regions themselves. Disparities may be noted both in terms of disconnection to urban processes and low accessibility to services.

The data-Table 2-bring us closer to the persistence of the accessibility gap in rural areas. In general, one-fifth of rural households say they have difficulties accessing food shops, banking services, health or education, being comparatively very small in metropolitan areas. But the gap is even greater in public transport. We should not only look at the fact that one-fifth of rural households indicate that they do not have easy access but especially that only a third of rural households use public transport. The difficulties of accessibility must be added to the deep lack of transport, as will be seen in the next section.

Throughout the twentieth century, different generations of rural modernization policies aimed at integrating these regions into national economies through the creation of connection infrastructures (roads, telephony, trains, bus lines). However, the criticism of the welfare state in favor of the rationality of the market under the neoliberal paradigm led from the 1980s onwards to the privatization and concentration of many rural services. Accessibility, which has traditionally defined the rural challenge (Moseley, 1979), remains today as a determining factor of its futures. Moreover, as a principal instrument for social and territorial cohesion, accessibility defines the degree and levels of citizenship, as it is a basic premise of modern societies. In this sense, the planning of rural accessibility has changed towards more holistic perspectives, and social inclusion is today the main objective of these policies (Farrington and Farrington, 2005). The Green Paper on Territorial Cohesion (Commission of the European Communities, 2008) considers three interrelated aims: overcoming differences in density (concentration), overcoming distance (connecting territories) and overcoming division (cooperation). The lack of accessibility and mobility are considered the determining factors of rural decline and regional development (OECD, 2006, European Commission, 2008, 2011).

However, as the Congress of Local and Regional Authorities (2017) pointed out, the crisis has shown the vulnerability of rural areas, even in relation to global shocks. All the processes that we are discussing here favor the increasing differentiation of rural areas (demographic ageing, the global financial crisis, technological disruptions). This, together with the reconfiguration of the maps for the provision of services or the deployment of infrastructures, results in true socio-territorial engineering that determines the personal projects and vital trajectories in the territories. The differences organized by the new accessibilities provided by socio-technical hybridizations and networks (roads, speed trains, broadband internet) produce specific types of rural landscapes (such as smart ruralities and remote regions, periurban areas and commuting districts). These very processes also include the possibility of relegating other territories to being a kind of new excluded periphery, remotely managed and monitored; for example, mountain and sparsely populated areas, border and coastal regions, inner peripheries.

\section{Automobility and mobility transition}

Although mobility is not the only source of accessibility or inequality, it becomes related to them in such a strategic way that it becomes substantial to the processes of transformation, resilience and hybridization of rural areas. The continuous mobilization acquired by modern life has changed the factors for the development, sustainability and decline. Daily mobility plays an essential role in the support of economic, residential and labor relations. For example, few technologies have so extensively reconfigured the socio-territorial relations as the car. Many residential and migratory patterns, labor strategies of long-distance commuting and ways of taking care of family responsibilities, can only be currently developed on the basis of the provision of the private automobile.

Accessibility to public transport is another of the characteristics that define the rural gap. As shown by Table 2 the population that does not use public transport is very high in 2012 and increased to $63.7 \%$ in contrast to $11.6 \%$ among residents in metropolitan areas. Besides the few rural users have great difficulty to access and $21.7 \%$ of rural users declare problems, five times more than the reduced $4.3 \%$ of metropolitan users.

Rural people need to use the car as the main alternative to move. There are sociological profiles and social conditions where the car's dependence to live in rural areas is essential. Table 3 shows the weight that it acquires in the Spanish case, for example, for young women, a group where the possession of the car is universalized, in deep contrast with the same group in the cities. The same is true of family groups with dependent children, in sharp contrast to the immobilized situation of women 65 and older.

Access to the personal car has led to a progressive permeability of the territory, blurring the countryside and the city, as well as some of the traditional rural disadvantages. But it is its generalization that exceptionally increases accessibility for many and allows for the settlement of strategic groups (such as the youth and women); it also establishes its own forms of exclusion and immobilization for others, and it erodes the public transport systems. Automobility options are crucial for stimulating social cohesion and jumping the rural gap. However, because of this fundamental importance of the car in rural areas, it has also become a key driver in the creation of new social inequalities.

The significance of mobility in disadvantaged and demographically vulnerable regions has been stressed by the 
Table 3 Households with car by degree of urbanization (Spain)

\% Houesholds with car

One-person household: men less than 30

One-person household: men between 30 and 64 years

One-person household: men aged 65 years and over

One-person household: women less than 30

One-person household: women between 30 and 64 years

One-person household: women aged 65 years and over

Two adults without dependent children at least one person aged 65 or over

Two adults without dependent children both aged under 65 years

Other household without dependent children

One adult with at least one dependent children

Two adults with one dependent children

Two adults with two dependent children

Two adults with three or more dependent children

Other household with dependent children

TOTAL

\begin{tabular}{lcl}
\hline Predominantly urban & Intermediate & Predominantly rural \\
\hline 56.9 & 53.7 & 70.1 \\
70.3 & 82.2 & 84.9 \\
46.5 & 44.4 & 55.6 \\
67.0 & 100.0 & 93.6 \\
57.9 & 78.7 & 72.8 \\
12.1 & 23.4 & 15.7 \\
67.0 & 71.7 & 73.3 \\
83.8 & 92.5 & 92.2 \\
86.0 & 91.1 & 90.9 \\
62.0 & 82.1 & 85.3 \\
91.6 & 92.9 & 97.5 \\
94.8 & 95.4 & 98.8 \\
90.1 & 94.4 & 89.9 \\
89.2 & 96.2 & 94.8 \\
73.3 & 81.8 & 81.2 \\
\hline
\end{tabular}

Committee of the Regions (2014). The challenges presented by public transport in these regions accumulate the effects of all the processes we have been discussing here. On the one hand, most ageing and sparsely populated areas, mountain regions and regions with problems of accessibility, areas that undergo deterioration of services and local economies, are those which depend to a greater degree on the efficiency of public transport systems. On the other hand, the costs of these services due to the previous, aforementioned characteristics, the fluctuation of the demand and the erosion that the private automobile entails, make their organization especially problematic.

The traditional considerations regarding the immobilism of rural societies have prevented an appreciation of how they have become configured during recent decades to an intensification of the daily mobilities. Furthermore, some studies (Milbourne and Kitchen, 2014) have described rural daily mobility as hypermobility. In this sense, we can consider that the deployment of forms under which the transition to other paradigms of mobility (shared, autonomous, unconventional) that are currently underway; these will largely determine the future of these areas and rural groups. A transition that, due to its characteristics, offers good opportunities for addressing the pressing mobility needs of these regions (on-demand buses and taxis, shared transportation systems and collective cars).

An essential issue is how this transition and its governance will be deployed in rural areas since, due to its core nature in these regions, the question should be considered as the management of a public good. Note, as Table 2 indicates, the strong lack of public transport in rural areas, a lack that clashes with the high mobility needs of residents in depopulated areas. Given the structuring function of mobility for accessibility to welfare and the rights of modern citizenship, it should be organized from an integral planning perspective within the regional systems.

\section{Conclusions: rural governance for socio-territorial balancing}

The budgetary constraints and austerity policies in Southern Europe have eroded the futures of the lagging regions in these countries (Boyer, 2012). The Spanish case, where ageing and poverty are often combined with the disadvantages of the habitat, has become an illustrative example of this process. Rural development policies aim to slow depopulation, organize the social agents in the territories and revitalize local economies. However, after the crisis, many territories have not managed to consolidate clear futures for the young. Almost half of the Spanish municipalities are threatened by depopulation, and even some inland regional towns have been losing inhabitants and show an outward migration of young trained people; this is connected to the lack of investments in services and infrastructures (Sáez et al., 2016).

The progressive rationalization of public services since the final decades of the last century and the impact of the recent economic recession have in a specific way deepened these socio-territorial fragilities (Woods, 2005; Moseley and Owen, 2008; Cheshire et al., 2012). While the rural areas that are better connected with the urban centers experience an important development due to the counter-urbanization, productive relocation or second residences; those less accessible regions show obvious disadvantages. In these last regions, the rural gap turns many of its inhabitants into a kind of 'second class citizens', as its consequences amplify internal social inequalities and the exclusion of the most vulnerable groups. As pointed by Woods, "Notably, many of the services that are most distant from the majority of rural communities-including hospitals, job-centers and benefit officesare those whose users are least likely to have access to their own private transport" (2005, p. 104).

Furthermore, demographic ageing has a widespread impact on the social organization, from the adaptation of housing environments to the provision of rural services or the reconfiguration of urbanized spaces. The complexity acquired by these processes can be observed in the demographic vulnerability of many rural border areas, where the problems of spatial accessibility are added in a process of cumulative causality; i.e., the groups immobilized or with a significant erosion of skills related to driving and movement at the same time have a strong demand for services such as health and welfare. These border areas are often located in the regional and state peripheries and they constitute the margins of the central economies. In this sense, European policies point to the need to implement transnational cooperation strategies, which would overcome the fragmentation and ineffectiveness of geographically limited approaches. Thus, these spaces, in spite of the social and geographical diversities could share similar solutions for its demographic and socioeconomic problems.

In rural areas, there is not only a greater demand for mobility due to the greater distance between places and habitat dispersion, but also due to a significant lack of public transport; furthermore, rural regions have much more fragile demographic structures and are characterized by more intense ageing than the urban ones are. Discriminatory geographies are neutralized in urban areas 
through infrastructures and collective transport networks, which make the right to mobility effective. However, in rural regions, the mobility question has become a more complex problem. Rural areas as a whole make up sociological environments that are more isolated and vulnerable, but that are highly demanding of services such as health, care and mobility. Finally, it is a world largely supported by private motoring. It is a dependence on the car that allows inhabitants to face up to and rebalance some of the previous disadvantages; for example, access to employment or external training, although this also leads to new inequalities.

The adequacy of mobility and the transition to new models can provide more equal conditions for the inhabitants of rural areas. However, just as the commitment to innovation and economic development has been unable to stop the depopulation and rural decline, it may in the same way be presumed that mobility and attention to accessibility cannot guarantee territorial rebalancing either. The rural challenge shows the depth of territorial imbalances and the strong association they have with demographic imbalances. The social agenda to face this challenge must interpret the demographic imbalances in terms of the generational relationships that constitutes the basis of social sustainability. Beyond the material issues of economic opportunities and access to wellbeing, what really shows the generational gaps and the strong asymmetry between men and women in areas of low density and population dispersion, is the difficulty of establishing, maintaining and developing vital projects in rural areas. Rural policies need to include the question of improving the attractiveness of rural areas for the development of life projects. With regard to this objective, the transition of mobility must be included. The transition should be considered within the logic of not only of the management of displacements, but also of a key mechanism to favor gender equality and generational diversity. Mobility must be thought out and organized for the purposes of conciliation, health, education, leisure etc., which attend to the different ways of life purposes. Mobility is a way to lessen the rural gap.

As we have tried to show, from the premise of the right to equal social conditions, the very territory produces disadvantages in terms of accessibility. Therefore, we can say that welfare is territorially distributed, and that mobility systems and connectivity are decisive to providing balanced social capital in rural regions. In other words, both rural-urban hybridizations through mobilities and global virtual proximity favored by telecommunications are the fundamental drivers for social cohesion and rural development.

\section{Data availability}

All data used are indicated in the paper.

Received: 19 March 2019 Accepted: 31 July 2019

Published online: 20 August 2019

\section{References}

Bayona-i-Carrasco J, Gil-Alonso F (2013) Is foreign immigration the solution to rural depopulation. The Case of Catalonia (1996-2009). Sociol Rural 53 (1):26-51

Bock B (2019) Rurality and multi-level governance. Marginal rural areas inciting community governance. In: Scott M, Gallent N, Gkartzios M (eds) The Routledge companion to rural planning. Routledge, New York, p 103-113

Boyer R (2012) The four fallacies of contemporary austerity policies: the lost Keynesian legacy. Camb J Econ 36(1):283-312

Camarero L (2009) The rural population in Spain. From disequilibrium to social sustainability. Barcelona, La Caixa Foundation

Camarero L, Cruz F, Oliva J (2016) Rural sustainability, inter-generational support and mobility. Eur Urban Reg Stud 23(4):734-749
Cheshire L, Higgings V, Lawrence G (2012) Rural governance: international perspectives. Routledge, London

Collantes F, Pinilla V, Sáez L, Silvestre J (2014) Reducing depopulation in rural spain: the impact of immigration. Popul Space Place 20(7):606-621

Commission of the European Communities (2008) Green paper on territorial cohesion. Turning territorial diversity into strength. COM (2008) 616 Final, Brussels

Committee of the Regions (2014) Opinion of the Committee of the Regions on 'Mobility in geographically and demographically challenged regions'. Offi J Eur Union. (2014/C 415/05)

Congress of Local and Regional Authorities (2017) A better future for Europe's rural areas. Governance Committee, Resolution 422, CG33(2017) 16 Final. 19 Oct 2017

Delivorias A, Sabbati G (2015) EU demographic indicators: situation trends and potential challenges. EPRS, 2015

Elshof H, Haartsen T, van Wissen L, Mulder C (2017) The influence of village attractiveness on flows of movers in a declining rural region. J Rural Stud 56:39-52

ESPON (2017) Policy Brief: Shrinking rural regions in Europe. Towards smart and innovative approaches to regional development challenges in depopulating rural regions. Posted on October 23, 2017. https://www.espon.eu/sites/ default/files/attachments/ESPON\%20Policy\%20Brief\%20on\%20Shrinking\% 20Rural\%20Regions.pdf. Accessed 30 July 2019

Fleming P, Sinnot M (2018) Rural physician supply and retention: factors in the Canadian context. Can J Rural Med 23(1):15-20

European Commission (2008) Poverty and social exclusion in rural areas. Final study report. European Communities, Brussels

European Commission (2011) Poverty in Rural Areas of the EU. EU Agricultural Briefs

Farrington J, Farrington C (2005) Rural accessibility, social inclusion and social justice: towards conceptualization. J Transp Geogr 13:1-12

Goll M (2010) Ageing in the European Union: where exactly? Statistics in Focus 26/2010. Eurostat

Green M, Hulme D (2005) From correlates and characteristics to causes: thinking about poverty from a chronic poverty perspective. World Dev 33 (6):867-879

Hite J (1997) The Thunen model and de new economic geography as a paradigm for rural development policy. Rev Agric Econ 19(2):230-240

Legido-Quigley H, Otero L, Parra D, Alvarez-Dardet C, Martin-Moreno J, McKee M (2013) Will austerity cuts dismantle the Spanish healthcare system? BMJ 346:\{2363

Lefebvre H (1967) Le droit à la ville. L'Homme et la société 6(1):29-35

Lesthaeghe RJ (2007) Second demographic transition. In: Ritzer G (ed) The Blackwell Encyclopedia of Sociology. Blackwell Publishing, Oxford

Li Y, Westlund H, Liu Y (2019) Why some rural areas decline while some others not: an overview of rural evolution in the world. J Rural Stud https://doi.org/ 10.1016/j.jrurstud.2019.03.003

Malecki EJ (2003) Digital development in rural areas: potentials and pitfalls. J Rural Stud 19(201):214

Margaras V (2016) Sparsely populated and under-populated areas. European Parliamentary Research Service (EPRS). PE 586.632. http://www.europarl. europa.eu/RegData/etudes/BRIE/2016/586632/EPRS_BRI(2016)586632_EN. pdf

Marsden T, Lowe P, Whatmore S (1990) Rural restructuring: global processes and their responses. David Fulton, London

Meijers V, van der Wouw D (2019) Struggles and strategies of rural regions in the age of the 'urban triumph'. J Rural Stud https://doi.org/10.1016/j. jrurstud.2019.01.027

Milbourne P, Kitchen L (2014) Rural mobilities: connecting movement and fixity in rural places. J Rural Stud 34:326-336

Ministerio de Política Territorial y Funciónn Pública (2019) Despoblación, reto demográfico e igualdad (Depopulation, demographic challenge and equality) https://www.mptfp.gob.es/dam/es/portal/reto_demografico/

Documentos_interes/Despoblacion_Igualdad.pdf0.pdf. Accessed 30 July 2019

Moseley M (1979) Accessibility: the rural challenge. Methuen, London

Moseley M, Owen S (2008) The future of rural services in rural England: the drivers of change and a scenario for 2015. Prog Plan 69:93-130

OECD (2006) The new rural paradigm: policies and governance. OECD Publications, Paris

OECD (2016) OECD regional outlook 2016. Productive regions for inclusive societies. OECD Publications, Paris

Oliva J, Camarero L (2019) Mobilities, accessibility and social justice. In: Scott M, Gallent N, Menelaos G (eds) Routledge companion to rural planning. Routledge, London, p 296-303

Sáez L, Ayuda M, Pinilla V (2016) Pasividad autonómica y activismo local frente a la despoblación en España: el caso de Aragón analizado desde la Economía Política. AGER 21:11-41 
Sampedro R, Camarero L (2018) Foreign immigrants in depopulated rural areas: local services and the construction of welcoming communities. Soc Incl 6 (3):337-346

Saraceno Ch (1994) The Ambivalent Familism of the Italian Welfare State. Soc Polit 1(1):60-82

Savage M, Warde A, Devine F (2005) Capitals, assets and resources: Some critical issues. Br J Sociol 56(5):31-48

Shucksmith M (2010) How to promote the role of youth in rural areas of Europe? Directorate General for Internal Policies. Policy Department B: Structural and Cohesion Policies. Eur Parliam PE 438:620

Shucksmith M, Brown D (2016) Framing Rural Studies in the Global North. In: Shucksmith M, Brown D (eds) Routledge international handbook of rural studies. Routledge, New York, p 1-26

Shucksmith M, Chapman P (1998) Rural development and social exclusion. Sociol Rural 38(2):225-242

Soja E (2010) Seeking spatial justice. University of Minnesota Press, Minneapolis

Van de Kaa DJ (1987) Europe's second demographic transition. Popul Bull 42 (1):1-59

Vidickienè D (2017) Attractiveness of rural areas for young, educated women in post-industrial society. East Eur Countrys 23:171-189

Weist K, Leibert T (2013) SEMIGRA selective migration and unbalanced sex ratio in rural regions. Targeted Analysis 2013/2/15. Leibniz Institute for Regional Geography; ESPON

Woods M (2005) Rural geography. Processes, responses and experiences in rural restructuring. Sage, London

\section{Acknowledgements}

This paper has been funded by the Spanish Plan for Scientific Research through the research projects: "Mobilities, Social Diversity and Sustainability-CSO2012-52862"
(2012-2016) and "Socio-spatial Research and Rural Development Network. Iso-RuralCSO2016-81728-REDT”(2016-2019).

\section{Additional information}

Competing interests: The authors declare no competing interests.

Reprints and permission information is available online at http://www.nature.com/ reprints

Publisher's note: Springer Nature remains neutral with regard to jurisdictional claims in published maps and institutional affiliations.

(c) (i) Open Access This article is licensed under a Creative Commons Attribution 4.0 International License, which permits use, sharing, adaptation, distribution and reproduction in any medium or format, as long as you give appropriate credit to the original author(s) and the source, provide a link to the Creative Commons license, and indicate if changes were made. The images or other third party material in this article are included in the article's Creative Commons license, unless indicated otherwise in a credit line to the material. If material is not included in the article's Creative Commons license and your intended use is not permitted by statutory regulation or exceeds the permitted use, you will need to obtain permission directly from the copyright holder. To view a copy of this license, visit http://creativecommons.org/ licenses/by/4.0/.

(C) The Author(s) 2019 